\title{
CARL F. H. HENRY ON THE PROBLEM OF (GOOD AND) EVIL
}

\author{
EDWARD N. MARTIN*
}

Liberty University

\begin{abstract}
Carl Henry devotes a few chapters directly (and a few indirectly) in volume 6 of his God, Revelation, and Authority [GRA] to the problem of evil [POE]. The author examines Henry's contribution as a theologian, noting that GRA is a work of theology, not philosophy proper. However, Henry had a PhD in Philosophy (Boston, 1949), and one finds present several presuppositions and control beliefs that are philosophically motivated. Observation of the text reveals several of these. Chief here is Henry's working assumption that to understand and explain the nature of evil, one must first understand and explain the nature, origin and etiology of good. This point and its implications are developed at length in this article. Unsurprising is Henry's contribution exhibiting an awareness of methods and theodical approaches traditionally used by philosophers of religion such as Rowe, Plantinga, and Hick. Surprising is the fact that Henry does not clearly take a side on the nature of human free will. What he does say seems to underdetermine his exact position. Finally, the importance of Kant vis a vis Henry's theodicy and entire theological program is emphasized as well.
\end{abstract}

KEY WORDS: Carl F. H. Henry, problem of evil, theodicy, Christian theology, Kant

When Carl F. H. Henry published the sixth and final volume of his magnum opus God, Revelation, and Authority [GRA], in 1983, the literature of the problem of evil was in a time of significant new developments. When Henry wrote this work, he wrote of course as a leading theologian within evangelicalism. So, what authors, concepts, definitions, angles, and so forth would he cover in his examination of the problem of evil while writing in a leading series on evangelical theology, ranging some 3000 pages? It is the purpose of this paper to investigate Carl Henry's contribution to the problem of evil, and suggest some major themes of that contribution. One theme that I have found woven throughout these various chapters on evil in Henry's work is one that will not be terribly surprising, but is important nonetheless: there is a parallel with Henry's treatment of the problem of evil and with his treatment of the history of ethics and of his treatment of Christian ethics. In 
short, there is a strong sense in which the Christian solution to any problem of evil is, it seems to me, hooked up in Henry's mind, with the Christian solution to the problem of good. Again, this is not a surprising development, for starting in the Christian tradition with Jesus, and St Paul, and running as a strong current through Augustine and down through the Reformers, and certainly onto Christian apologists and writers in our own day, such as C S Lewis, is the notion that one cannot get straight on the meaning, significance, and purpose of real evil without there being a real good that stands in theoretical and practical contradistinction to the evil (Lewis 1960: 49).

\section{The Problem of Evil, Good, and Divine Command Morality}

First, though: what is the problem of evil? For that matter, what is evil? As a first validation of one of our observations above, namely, how Henry ties together issues of ethics and issues of evil, it is important to note that Carl Henry is a proponent of a famous Christian position in ethics known as divine command morality. Roughly, his position in ethics is that the good is that which is in accordance with God's will. Evil, then, is defined in a straightforward way: 'Evil is therefore whatever opposes God's revealed will and word' (Henry 1983: 258). Many ethicists have been very slow to define good and evil, saying rather that these terms are so basic, so fundamental to the ethical enterprise, that they are actually as a result undefinable and noncomplex, i.e. simple. Simple, ethical primitives such as these do not admit of connotative definition, it is widely held; however, one may use these atomic units to build up to other molecular, complex ethical terms (such as rightness, equality, and perhaps even neighborly love). How, then, does one know the meaning of good and evil? To these theorists-and I especially have ethical intuitionists such as G. E. Moore in mind here (Moore 1903), one comes to 'know' what good and evil are simply by acts of one's moral intuitions-a phrase popular in the ethical literature of our own day. I shall state throughout this paper that I shared various similar experiences (some sort of interesting) in the course of our individual lives (with a few intersections of which I'll speak, later) to those of Professor Henry. One of them is that during our $\mathrm{PhD}$ programs in philosophy, we each had to prepare for and take comprehensive examinations in ethics. Henry speaks to this in the preface to his Christian Personal Ethics, which was my first exposure to Henry's published work (though not to Henry himself-I'll explain later) in a course I had in Christian and Greek Ethics in the Spring of 1988 at Hillsdale College in Hillsdale, MI. There, Henry writes that to prepare for the comprehensive ethics exam at Boston, both the approved reading list and the lectures by Edgar Brightman 'moved solidly in the idealistic tradition.' 'There was a semi-concealed, albeit gentlemanly, distaste for an ethic or religion of special revelation' (Henry 1957: 16). Henry mentions that what he 
received from Brightman, in the 'idealistic' tradition, was an ethics based on human autonomy, in the post-Kantian tradition (Henry 1957: 16). Before arriving at Boston, Henry writes, he attended Indiana University, in whose philosophy department he met with professors whose bent included that of a Thomist, a post-Kantian, and 'a Calvinist its chairman'. Note that this chairman was Professor W. Harry Jellema, who later was the teacher of Alvin Plantinga at Calvin College, another towering figure in 20th century Christian thought. Both give exceedingly high praise to Jellema's ability to show the bankruptcy of secular ethics and philosophy in favor for one based on revelation from above. However, despite Christian ethics' reliance on revelation, still Jellema 'portrayed Christianity, despite its divine and revelatory nature, as an ethics of cognitive and philosophical implications.' 'Jellema... taught secular ethics, a course in which he unhesitatingly acknowledged Christian ethics as the source of weighty answers to some of the unresolved problems of speculative morality' (Henry 1957: 16). One need only piece through Personal Christian Ethics to see how Jellema's strong direction and impact has left its mark on Henry's text. The point to see here is that Henry, despite the perennial objection of the Euthyphro Dilemma for divine command morality theories, was a lifelong adherent to this type of ethical theory, a theory that said that the good just is that which is in accordance with God's will and his revealed plan and providence.

\section{Kant's 'Crudely Circular Explanation'}

Another theme we see in Henry's GRA and its treatment of the problem of evil (and of the problem of good) is that Henry is philosophically quite subtle and nuanced, even on some occasions showing a keen awareness of philosophical issues to a problem fairly early on compared to some of the literature pockets that would follow and points that would be developed in future years and decades in the philosophical and theological journals and monographs. E.g., Kant had pointed out a 'crudely circular explanation' with any ethics based on the (a) 'theological concept,' such as divine command morality's defining $\mathrm{x}$ is good meaning that $\mathrm{x}$ is 'in accordance with' God's will or revelation (Kant 1981: 47). What is Kant getting at here? Is this different from the Euthyphro Dilemma? I believe it is somewhat different from Euthypho's problem-though it is somewhat related.

The objection that Kant may have in mind, the issue at hand for divine command morality, which leads to a 'crudely circular explanation', may be the following. Suppose we define:

Good (DCM): $x$ is good just means that $x$ is in accordance with God's will or revelation. 
So, if we plug in loving your best friend, we say that loving your best friend is 'good' just means that loving your best friend is in accordance with God's will or revelation. To Christian ears, this seems quite reasonable: God is a person, after all, and he is the person who is responsible for our existence, and the existence of all things in heaven and on earth. That is, he is the creator. He is also the sustainer-he holds things in existence once he has called them forth out of nothing (see Colossians 1:17, Hebrews 1:3). God is the ontological source, indeed, according to the theist, of all things that are neutral and of all things that are good. And, if he is the person that stands behind all things that are good, God would also stand behind and put his impression upon good things. That is, he would will good things for his creatures, and especially for his people, made once in his image, and, now being restored in that image and likeness.

However, if we were to ask: what is the status of God's will or revelation: is it good? If we use our formula (Good (DCM)), above, we run into an interesting issue. For, plugging in for $\mathrm{x}$ what we want to find out here, the result is that God's will is 'good' just in case God's will (or revelation) is in accordance with God's will (or revelation) (Linville 1990). But what substantive claim can possibly be made by saying that x's will is in accordance with x's will? That essential means that whatever God wills is... just what God wills. But of course whatever Zeus wills would be in accordance with what Zeus wills, whatever Robert De Niro wills is in accordance with what Robert De Niro wills, and whatever I will is in accordance with what I will. How could these not be true, even by a 'crudely circular' definitional sort of way? Isn't it just empty, then, of significance to say that God's will is good, if all that that means is that God's will is in accordance with God's will? I suppose the answer is yes; however, Christian theologians-among whom is numbered Carl Henry-have thought (and no doubt prayed) about this issue for a long time and have developed sophisticated and contoured answers to this issue. E.g. one answer is to say that there is something deeper in God, beyond God's will, that really should be plugged into the right side of DCM's definition of 'good', above. Call it Good':

\section{Good' (DCM): $\mathrm{x}$ is good means that $\mathrm{x}$ is in accordance to God's nature or character.}

This powerful response is helpful because according to the likes of the biblical authors, Augustine, Aquinas, and a host of other theologians, God's nature is the same, always, without end. God, as we say, does not change. God is not like 'shifting shadows' (James 1:17): 'I the Lord do not change' (Malachi 3:6). God, as philosophical theologians tell us, is immutable. Now there are different ways of understanding the concept of divine immutability. But 
the main point here is that God does not change-not in this world, and, to use a subtle modal distinction, not in any possible world. Philosophers often invoke the language of possible worlds in this context to say that not only does God have a moral perfect and omni-benevolent character in this world (call this world 'Alpha' for short), but also God has the same character in all possible worlds at which he exists-and, as most theologians (perhaps) would nowadays say, God exists at all possible worlds. So, to reprise what we did above between definition Good (DCM) and Good' (DCM) can take the following form. If a divine command moralist defines that which is good by linking it to the will of God, a potential weakness is that a will is a metaphysical entity that can potentially choose differently, could choose an alternative possibility, it seems, prima facie. That is, in this world, in Alpha, God willed to create Moses, but if Beta (some alternative possible world) had been actual, and Beta was such that in it there were no human creatures at all, then presumably God would not have willed to create Moses in Beta. The act of some person P's willing, and more particularly the state of P's being free with respect to some action $\mathrm{A}$, where $\mathrm{P}$ is a possible being, seems to entail worlds in which $\mathrm{P}$ exists and performs action $\mathrm{A}$, and worlds in which $\mathrm{P}$ exists but does not perform action A. This is called the PAP, the principle of alternative possibilities. The nature of a will as an entity is to perform some actions in some worlds, and, if actual in another world, to at least have the possibility of acting in a way different from the way it acted in another world. So, a common way that divine command moralities strengthen their ethical position is to define Good as Good' (DCM), as above, and to refer to the immutable nature, essence, and character of God across all possible worlds. This is a definite advance in the formulation of DCM.

\section{The Further Objection (now against Divine Nature Morality)}

Now, obviously, the objector to Good' (DCM) is simply going to ask: OK, well what about this question: What is the status of the nature or character of God; is it 'good'? One has, the objector will say, only pushed the problem of another level: one is just delaying, stalling as one tries to come up with a non-circular answer to the problem that has been identified.

Well, maybe that is so, but we have at least showed that the goodness of God now, at least, does not simply lie in something that changes (or could change) from world to world-God's will-but rather have tied the goodness of God to something immutable, something that necessarily is the way that it is - the nature of God or the character of God, which is the same (i.e., has the same essential properties) at every possible world that there is. Henry here shows that he is well aware of the subtleties regarding divine command morality: 
Ancient, medieval, modern and contemporary philosophers mount prestigious intellectual support for the contrary view that man's own moral sense must decide whether God is good and whether we ought to obey him. Ever since Plato's Euthyphro (9e) the view that God commands what is independently moral has been ranged against that emphasis that God's free choice and command are what makes actions obligatory. William of Occam's contention that no act is incapable of becoming a good act if God commands it (Sentences, Book II, qu. 19, ad. 3 and 4) provoked sharp rebuttal. Suarez, for example, comments that God cannot abolish what natural law approves. But what divine command moralists stress, of course, is that God neither acts contrary to the justice he voluntarily approves nor contrary to ethical categories he has implanted by creation in his image-bearing rational-moral creatures (Henry 1983: 254). [emphasis mine]

Henry can say that God does not act contrary to the justice that God wills, nor against the very moral intuitions that God himself instilled within his moral agents that bear his image, because to do so would be to be morally inconsistent, to fall short in action. In other words, since God is not just benevolent, but perfectly benevolent, he is 'transworld benevolent'. God has, we might say, transworld benevolence-I, like Alvin Plantinga, leave it as homework to compare this notion to what Plantinga says about what may possibly be our plight as humans, namely, having 'transworld depravity' (Plantinga 1974: 48).

In a similar context, Henry concludes (therefore) about the phrase 'God is good':

[Atheist Kai] Nielsen maintains that the statement 'God is good' is one of evaluation and not one that establishes identity, else Christians could not affirm additionally that God is literally a transcendent person. Our reply to Nielsen is not, as R. B. Braithwaite contends, that Judeo-Christian metaphysical affirmations should be collapsed into moral claims (An Empiricist's View of the Nature of Religious Belief), or as Terence Penelhum contends, that religion involves nonliteral mystical utterances ('Faith, Fact, and Philosophy', 99); as Nielsen is aware, such capitulations would abandon the intellectual intention of historical Judeo-Christian theism. For biblical religion 'God' is rather a descriptive term having evaluative significance; its evaluative force depends upon its descriptive content, a content transcendently given (Henry 1983: 255).

Henry is saying that God reveals himself from on high as having this and that desire, will, goal and purpose. These purposes and God's will are not merely descriptive for us. Rather, God has a moral authority over us because he designed us as moral beings, and planted within us our very moral intuitions that 'make us tick', so to say. Given that God has made us in his image, it means in effect that those human moral intuitions, at least pre-fall (before they may have been twisted by a fallen nature, will, and character), were completely in line with God's will, which is completely in line (must be 
in line with-at every possible world) God's perfectly moral character. God's utterance is good because God's utterance is in line with his will, which reflects his nature. Isn't God's nature, though, simply in accordance with his nature? Henry here says that 'God' is rather a descriptive term 'having evaluative significance'. First, 'God' here is an office; 'Yahweh' is after all the name of God. Whoever it is who holds the office of God-that would be descriptive. I think Henry is tracking the truth here. However, the historicalsalvific fact is that God is a God who speaks and shows (which is a phrase mentioned in the subtitle of GRA's first three volumes). God has created us; God has created us in his image; God has sustained us; God has revealed to us through words: God has spoken to us. God has the nature qua God to be the Lord over us: to have authority over us. So, I think Henry is saying that God, by dint of being the office holder of our creator, sustainer, designer, father, Lord, the one in whom we move and live and have our being, in effect, God's command is powerful and active: His command for us is obligatory, not unlike a good earthly father's command is obligatory upon the father's children. God rightfully commands our allegiance. As Jesus himself declares, 'There is none good but one, that is, God' (Matthew 19:17, KJV), a text which Henry cites in this context (Henry 1983: 257).

\section{Henry on Evangelicalism's Opportunity: I, 'Kant', Understand the Times}

Let's take stock of some of the things that we have discovered so far, while expanding upon them. The name of Henry's greatest work, after all, is God, Revelation, and Authority. As Bob Patterson points out, there are traditionally eight parts of theology covered in systematic theology: God, revelation, creation, anthropology, Christology, soteriology, ecclesiology, and eschatology (Patterson 1983: 160). Henry funnels all of these eight through the sieve of 'God' and 'revelation', while adding 'authority'. Patterson writes, 'Henry has not given equal time to each doctrine since he is not trying to write an evenly balanced textbook in systematics. Rather, he has focused on revelation and God, and the other six doctrines blend into his treatment of these two doctrines. He has deliberately chosen this format because he feels that revelation and God are the crucial doctrines at this stage of the twentieth century, and this two-foci style suits his apologetic thrust' (Patterson 1983: 160). Henry received both a $\mathrm{ThD}$ in theology and a $\mathrm{PhD}$ in philosophy, and through these studies became convinced, as seen in his book in 1948, Remaking of the Modern Mind, that as the mantle of the secular Western worldview was passing into shadow, it was an opportune time for evangelical theologians and philosophers to step up and fill in the vacuum left behind with a worldview that met humankind's deepest spiritual, intellectual, emotional, psychological and communal needs. This conviction never left 
Henry, and indeed his monumental GRA continued to work out this vision that Henry had (Henry 1948).

There is a saying that's been around for a long time about the Prussian Enlightenment figure Immanuel Kant's contribution to philosophy and philosophical theology: Kant is so important that one can either philosophize with Kant, or against Kant, but one cannot philosophize without him. Kant gave us the critical philosophy, including three 'Critiques': the Critique of pure reason, practical reason, and of judgments (esp. aesthetic and teleological judgments). Kant held that unlike Locke's picture of human epistemology wherein the mind is passively written upon by the manifold of experience-the mind is sort of like a really trustworthy mirror, and experience in-forms that mirror, which then accurately reflects reality, the mind actively adds very important elements to the process of empirically knowing about the world around us in a way that is absolutely necessary to the proper perception of the world. In fact, the contribution that the mind makes, Kant said, was a necessary a priori condition of empirical cognition. What does the mind contribute? The categories of the mind allow us to see the world as one outfitted for human cognition; it allows us to make sense of the energy and movement in the world that without mind's active ordering would leave the world mere 'buzzin', blooming confusion', to use a line from William James. The mind, for Kant, synthesizes the manifold of experience in such a way that we see the world as lawlike, orderly, properly causally structured, having substances, being in both space and time, and the like. In Kant's Critique of Pure Reason, 'Transcendental Aesthetic', an early section on Space contains this point, which drives home some of these points, above:

(b) Space is nothing but the form of all appearances of outer sense. It is the subjective condition of sensibility, under which alone outer intuition is possible for us. Since, then, the receptivity of the subject, its capacity to be affected by objects, it can readily be understood how the form of all appearances can be given prior to all actual perceptions, and so exist in the mind a priori, and how, as a pure intuition, in which all objects must be determined, it can contain, prior to all experience, principles which determine the relations of these objects (Kant 1965: 71 [A26/B42]).

I cite this famous Kantian passage (and many more like it could have been given) because in it Kant shows his famous 'second Copernican Revolution': in order for the human mind to know the table's in the room, it's not that the mind must conform to the table (that's Locke and traditional empiricism); rather, the table must conform to the mind and what it 'brings' to human experience: all empirical experience as a human must be temporal, and must be spatial, because it is these forms that the mind contributes to hu- 
man empirical experience. Kant says here that the form of all appearances-all things that appear to our consciousness, at least regarding an awareness of things ad extra, coming to us from without us, that is, from the external world, must conform to these principles, form and categories which 'determine the relations' of these objects. Importantly for our purpose, for Kant this means that we can only say that we know those things that are spatial and temporal. Since God, freedom and immortality by definition are outside space and time, God and these other things cannot be known. In short, Kant's argument goes something like this:

1. If God is not in space and time, then God cannot be known. (Kantian premise)

2. God is not in space and time.

3. So, God cannot be known.

This argument takes the most basic form of valid argument form, modus ponens: If $\mathrm{P}, \mathrm{Q} ; \mathrm{P}$ is the case; thus, $\mathrm{Q}$.

Henry's counterargument as seen in most places in his works after Remaking the Modern Mind, is:

1. If God is not in space and time, then God cannot be known. (Kantian premise)

Not-3. But God can be known.

Not-2. Thus, it's not the case that God is not in space and time.

Henry's argument uses an equally valid argument form, modus tollens, which shares the same first premise with modus ponens, but then reverses and switches the second premise and the conclusion: If P, Q; not-Q; thus, not-P.

\section{The Incarnation and the Gospel of John as an Answer to Kant}

By putting things as I have, above, I do not mean to say that Henry has vastly revised his doctrine of God, saying that God is finite, temporal and spatial, in order that we may know him. Such a move would be a too-costly capitulation to Kant's anthropology. Rather, what I mean to point out is that since God is Lord over space and time, according to evangelical and classical theology, God is not subject to space and time, but being Lord over time God can reveal himself in and through time and space by his omnipotent, omniscient, omnipresent power, sovereignty and authority. (There's that word again.) And of course, one way that God does show his Lordship over time and space, as its creator, sustainer, and ultimately its redeemer (cf. Romans 8:18-23), is through the Incarnation. Henry's answer to Kant is found, as with all over problems and questions in all aspects of life, in the Holy 
Scriptures. I am profoundly grateful to Carl Henry, though I did not understand what I was in for at the time, for the answer, in the Holy Scriptures, that he gave to me. While I'll explain in a bit, let me just say that it was Carl Henry who was my first Bible professor, as a visiting professor at Hillsdale College, in a course on the Gospel of John in Fall 1985. Henry was a visiting professor there, teaching John and Church History. (My main religion professor at Hillsdale, Dr. Thomas Burke, had his M.Div. from Trinity Evangelical Divinity School, and invited Dr. Henry into various writing and speaking projects involving Hillsdale-even while I was there.) Henry thought that Biblical Christianity could always fill the vacuum where secular theories fell wildly short. Though we don't have to accept the Kantian premise no. 1 above, still, even if we play by the Kantian rules, the Scriptures have a ready reply:

From the fullness of his grace we have all received one blessings after another. For the law was given through Moses; grace and truth came through Jesus Christ. No one has ever seen God, but God the only Son, who is at the Father's side, has made him known.

Even supposing that God is outside space and time (cf. John 4:24, 'God is a spirit'), yet (a) God, being omnipotent, omniscient and the creator of our cognitive and spiritual faculties, knows how to communicate truth, love, and prophecy to us through the prophets, and (b) God, though he cannot be seen as a spirit, yet God 'the only Son', has 'made him known'. The word here is the Greek from which we get the word exegesis: the Son exegetes who the Father is, he makes him known to us. John 1:14 famously tells us that this divine logos, Jesus Christ, seen in John 1:1, became flesh and dwelled for a while among us. Reminiscent of a Roman court room testimony (and similar to the language of 1 John 1:1-4 in this regard), John tells us, "we have seen his glory, the glory of the one and only Son, who came from the Father, full of grace and truth.' Again, reminding us of John 14:9, those who have seen the Son have seen the Father. Those who have seen the Son have seen his glory. It is important to see that in scriptures, God does not share his glory with anybody else. This same John says of Jesus Christ that this one 'is the true God and eternal life' (1 John 5:20). The famous Dan 7 passage says that the 'son of man' will come 'on the clouds of heaven' (a direct, unmistakable reference to the son's being numerically identical to God). When Jesus applies these words to himself in Mark 14, his Jewish hearers tear his clothes and ask if there is any further need for evidence to warrant the charge of blasphemy. Daniel goes on: 'He approached the Ancient of Days and was led into his presence. He was given authority [sic], glory, and sovereign power; all peoples, nations and men of every language worshipped him' (Daniel 7:14). Again, Christ is God, for no created, non- 
divine, non-God individual can both receive worship and receive God's blessing for that worship. God does not share his worship with created beings.

\section{Goodness is Originative, Badness is Derivative}

So, the lesson here is that when one tries to read about the problem of evil in Henry's 6 volume work, as elsewhere, one first confronts the Christian revelatory claim that there is no use in understanding or even overcoming evil until we first know, love and appreciate the good, who is God. This a very Augustinian theme, even though Henry did not seem to accept the traditional Augustinian definition of evil as 'the privation of good' (privatio boni). Rather, Henry defines something evil as that which is against the divine will or revelation. The point between the two definitions of 'good' and 'evil' remains: Good is primitive, and evil is derivative. Good is primary, first in every sort of ordering (temporally, lexicographically, serially, in the order or preeminence, etc.) one can do; evil is secondary. Good is independent; evil is dependent on the good. As C. S. Lewis says, 'You can be good for the mere sake of goodness; you cannot be bad for the mere sake of badness... Goodness is, so to speak, itself: badness is only spoiled goodness. And there must be something good first before it can be spoiled' (Lewis 1960: 49). This latter reality is the reason why we have permission, as Christian believers, to solve the problem of good first, and only secondarily, to try to address the problem of evil. One can have an infinite, all-good being; one cannot have an infinite, all-evil being. God can exist without evil-and doubtlessly did (to speak loosely) 'before' the creation of the world and the resultant fall into sin by Satan and the rebellious angels-and by our own ancestors' rebellion against our good creator God. Evil is a parasite, always needing a host in which to dwell-and that host is the good. To understand good, Henry says, we must understand God. How do we understand God? We do this through theology, which is a knowledge or study of God's existence and attributes and actions. But, of course, if Kant is anything close to right, we cannot 'know' God-not, at least, as a spatial-temporal object. (Kant, in the second Critique, would try to argue that it is through morality, the 'ought' of moral experience, that we encounter a sense and meaning that cannot be accounted for by mere material, spatial, temporal means. There must be a transcendent moral authority who gives power to that moral word. Only God can do that in a way that stops all of our wonderings and wanderings. For he alone is just in excelsis, and has the character and eternal, necessary being to back up that just-ness across all possible worlds and situations.) Again, the answer to Kant comes from Scripture, where God is speaking:

Now what I am commanding you today is not too difficult for you or beyond your [even epistemic] reach. It is not up in heaven, so that you have to ask, 'Who 
will ascend into heaven to get it and proclaim it to us so that we may obey it?' Nor is it beyond the sea, so that you have to ask, 'Who will cross the sea to get it and proclaim it to us so we may obey it?' No, the word is very near you; it is in your mouth and in your heart so that you may obey it (Deuteronomy 30:11-14).

Henry's answer to Kant, then, would be that we do know of this God, our Creator, because God has made himself known to us. If God in his omnipotence was not able to do that, per impossibile, he would not have created us humans, but would have chosen some other species (perhaps blumans, or trumans, etc.) with whom he could communicate. The Kantian premise is faulty, Henry would argue, in effect, for many reasons, but one is that it puts a human autonomous attitude before God's theonomous, communicative action and essential being as 'the Communication': In the beginning was the Communication, and the Communication was with God, and God was the Communication! God is essentially communicative-verbal-and he loves to communicate his glory and his grace to his people.

After that enterprise, after our theological understanding of theology is achieved, at least at some initial scope, we then have a working knowledge, understanding, and definition of the good. It is at that point, then, that we would turn to the problem of evil.

\section{Henry's Treatment of the Problem of Evil in GRA}

When we turn to the GRA, we note that Henry does have a chapter in his final volume on 'God and the Problem of Evil' (chapter 12). In light of what we said above, it is duly noted that the chapter before the problem of evil chapter in GRA, volume six, is entitled 'The Goodness of God.' So, to reiterate, evil is a bastardization of the good-but good can exist independently of evil, so we have permission to do our theology of good first, our theory of the good, which is called theology, before we do our theology of evil, or our theoretical reply to the problem of evil. Chapter 13 of Henry's sixth volume, 'Evil as a Religious Dilemma', treating the existential or 'religious' problem of evil, comes (thus) after a chapter entitled 'The Goodness of God' and before 'The Fatherhood of God'. I should note that rather than citing Augustine in this context, Henry cites Aristotle, who had held that evil was a mere steresis or 'privation'. Henry is careful to say that Scripture seems to speak of evil as a 'reality', in and of itself. So, what are we to make of this point? I appreciate that he is toeing the line and asking, 'What does Scripture say about this point?' But the corrective that Augustine brought to the issue over Aristotle's sense of evil is the following. Aristotle, Henry says, held that evil is therefore declared to be not an ontological but merely a quasireality; it is something not made or caused by God but something whose continuance God allows to that it may be transformed into good' (Henry 1983: 295). Augustine's main point was to avoid ascribing any sort of moral 
responsibility for the origination of evil. However, I don't see where in Augustine that evil is merely waiting to be transformed (back) into the good host in which it dwells, so to say.

What, then, does Henry say about the problem of evil in his chapter of the same title in GRA, volume 6 (published 1983)? In summary, (a) Henry follows for most of the chapter John S. Feinberg's treatment of the problem, based on Feinberg's PhD dissertation on evil at the University of Chicago (1979) and published as Theologies and Evil (Feinberg 1979); (b) Henry cites many contemporary authors writing on the problem of evil then (Keith Yandell, John Hick, Michael Peterson, Alvin Plantinga, George Schlesinger, Antony Flew, J. L. Mackie, and Ninian Smart); (c) Henry does not refer to the new 'problem of evil' on the block at that time, the evidential argument from evil, e.g. of William Rowe (Rowe 1978, 1979); (d) Henry does, though, mention more or less the main points that Feinberg identifies as the chief issues about evil that most observers or skeptics wonder about, viz., the problems of the intensity, extent or quantity, and seeming gratuitousness of (some) evils (Feinberg 2004); however, (e) to get the fuller picture of what Henry responds to the problem of evil, one must also read the next chapter, chapter 13 entitled, 'Evil as a Religious Dilemma'; and (f) taking in both of these chapters together, we find that Henry covers not only these three questions that Feinberg identifies, above, but also touches on the hiddenness of God, God's non-intervention in the world when evils occur, how could God have given his permission to create such a world as this given the evil that God knew would surface throughout; what about the Holocaust? (which Henry addresses following chapter 20 and before the final chapter of the book and series, in a 'Supplementary Note: Auschwitz as a Suspension of Providence'), and of course the role of our epistemic limitations in this life: 'In this life not even the Christian has complete knowledge; Paul considered even apostolic revelation to be incomplete' (Henry 1983: 302); and, ultimately importantly, the role of the Suffering Servant in showing us what we might ourselves expect to suffer in this world, for surely Christ suffered most undeservedly, and he was morally perfect, committing no sin (Hebrews 4:15, etc.)—a fortiori, what are we to expect vis a vis suffering in this life?

\section{On Gratuitous or Seemingly Gratuitous Evils}

On the seemingly gratuitous nature of evils, Henry first mentions this term when citing the work of Edward Madden and Peter Hare, who write, 'Some evil obviously serves good ends. But much evil resists simple explanation; it is prima facie gratuitous. The really interesting problem of evil is... whether the gratuity is real and hence detrimental to religious belief' (Henry 1983: 284). A 'gratuitous evil' is usually defined something like this: an evil for 
which God would not have a morally sufficient reason to allow. After examining the question of the seemingly gratuitous nature of some evils we see in our midst from time to time, Henry concludes, 'Nowhere does the JudeoChristian revelation say that the living God allows gratuitous evils' (Henry 1983: 291). Henry refers to accidents that kill hundreds of passengers, and obviously as historical events, they come or 'occur', happen, and then are over. The substances affected by the crash of a plane-the bodies of living people-may be lost. Even in Christ's post-resurrection state, he still retains the historical scars upon his wrists and in his side, etc., for some function: no doubt, for the function of memory and a reminder and remembrance. But it is fascinating that those features were not removed and thus not renewed in the resurrected Jesus' body itself. (We get so used to CGI effects in movies and on video games now, which can erase scars and blemishes in the proverbial blink of an eye.) So, it strikes me that one can hold to the majority voice of Augustine on evil, but simply say that evils are clearly not simply quasi-goods, waiting to hop back into a good state again by divine fiat (or the like). Evils are real: so real, in effect, that Christ, while we were yet in open rebellion against him, 'died for us' (Romans 5:8). Henry writes, '[i]n the Bible evil is not gradually metamorphosed or finally transmuted into good but is ultimately subordinated by omnipotent divinity' (Henry 1983: 293). Here Henry speaks of the reality of hell, and close at hand is the fact that evil in the Bible always has an eschatological dimension to it: God may allow it now, but ultimately defeats sin, death and evil through the triumph of the death and resurrection and glorification of the Son of God and God the Son. Two quotations relevant here give the flavor of Henry's answer to the chief problems of evil: God is a wrathful God who will not forget to punish sin, wickedness and evil, caused by human beings and their rebellion against God. However:

For the merely hypothetical question raised by secular philosophers, viz., 'can this world's evils be reconciled with a sovereign good God?', God's selfmanifestation in Christ substitutes the far more comprehensive and profound question, 'What must I do to be saved?' (Henry 1983: 299).

... [W]hat shall we make of plane crashes that kill hundreds of passengers... and death-dealing terrorism?... of war? Are such grievous misfortunes to be subsumed simply under generalizations that disguise all human suffering as some kind of metaphysical blessing and benefit? Can we sanctify the senility... Does not the heaped up accumulation everywhere and generation after generation of pain and suffering erase any hope that a sovereign benevolent deity creates and sustains human life? None of these concerns and apprehensions fall outside the biblical purview; Job's detailed experiences anticipate Pauls' assurance in Romans 8 that for the family of God all things do indeed fall within God's providential will and care because God himself controls the very circumstances that threaten the best of us. Life is not wholly without meaning and value; if Jesus is 
to be believed, and he is, our prospect of blessedness is secure. Christ's earthly life with all its seeming tragedy demonstrates how we may confidently call God good and how we, too, may trust his vindication of the good (Henry 1983: 301).

\section{The Suffering Servant as a (the?) Christian Answer to Suffering Meaningfully}

Again, there is much in the Holy Scriptures to find about suffering that can help the sufferer to identify with Christ in his suffering. Scripture invites this, speaking of those who will become 'heirs with God, and co-heirs with Christ, if we share in his sufferings in order that we may also share in his glory'. (Romans 8:17; my emphasis). What is a Christian saint living today to think of such a passage, when history's river has flown and there seems no way to get back 'there' in Jesus' time to 'share in' his suffering? Are we all therefore lost? But clearly there is a biblically-charged and warranted view of metaphysics that must be invoked here to make sense of this passage. The Sovereign God, the 'knower of our hearts' (cf. Acts 1:24; 15:8) can 'count as sharing in' Christ's suffering whatever he pleases to count, even pro- or retrospectively, in his omniscience. As Henry says:

Jesus' cry of dereliction pinpoints the fullest meaning of the issue: 'My God, my God, why hast thou forsaken me?' It is into this why of Calvary that we can channel every other 'forsaken' me of human experience for Jesus the unique Son has an incomparably greater claim on the Father's love than do any of us. Is there any answer to this cry of desolation more appropriate than that this created universe is a divinely botched job, a clumsy cosmic blunder? Perhaps we could remind [Antony] Flew that is Jesus' case-even if it seemed even to Jesus' friends to come too late-the answer came not only in the best of time but also in the best of ways (Henry 1983: 299).

It is, after all, called Good Friday.

\section{Three Peculiar Claims or Absences in Henry's Account}

Let us conclude our coverage of Henry on evil with three closing remarks.

(1) It is expected to be given the exact definition of human free will that the theologian will be working with when talking about the problem of evil. It is a bit strange that Henry does not lay out his definitions for us. He would doubtlessly simply read off of the biblical text that Adam was responsible for his open rebellion against God, and thus Adam brought about that rebellion, and thus was 'free' in some sense of 'free'-a sense sufficient to secure personal responsibility, for example. He cites Feinberg through the chapter, most of the time seemingly approvingly, but while Feinberg is a compatibilist Calvinist, Henry does not seem to approve (or disapprove) that part of Feinberg's presentation. Yet, Feinberg's work Theologies and Evil focuses on 
this very point: That each theology has its own problem of evil to solve, and thus one must look to one's definitions of God, omnipotence, omniscience, free will, depravity, hell, judgment, etc., in order to solve the problem of evil that arises within that particular set of theological tenets. Different theologians (and thus different believers) will have different problems to solve. So, there just isn't that debate or claim in the text, and that is unusual. A similar criticism might be leveled concerning divine omniscience, and even divine omnipotence, two attributes of God that Henry does not try to define in this context and apply in these highly relevant contexts in which the meaning of those terms can make significant shadings and colorings of meaning and intonation regarding evil. Is Henry a Molinist, or, does he think that counterfactuals of creaturely freedom have truth value? Don't expect an answer to questions like this from the text. The closest Henry comes to affirming some sort of free will occurs in this text, it seems to me:

I share Feinberg's insistence that good and evil must be defined not by their consequences but by divinely given norms; that solution of the problem of evil must not distort God's character or alter his intention for man and the world on the basis of creation; that personal desire bears in important ways on personal guilt for sin; and that God created a universe in which humans cannot act other than they voluntarily do (Henry 1983: 273).

It should be noted, however, that Henry, though not extensively, does exhibit some of the techniques that philosophers of religion often engage in also when thinking about God and evil. One important method is what John Hick calls the method of counter-factual hypothesis, which is simply when one asks what would have happened if this other course of action, or world detail, or the like, had been actual instead of the way things went in this world? (Hick 1977: 334). The context in which Henry employs this helpful method to theodicy is with the biblical theodicy problem of Yahweh's command to exterminate the Canaanites. The method can be seen here when Henry remarks, 'God's temporal punishment of the heathen in Palestine was in fact incidental to his larger purpose, that of providing salvation for mankind through a redemptive history threatened by the Canaanites' (Henry 1983: 295). Other common methods can be seen in Henry, but often they are left in a more germinal state and not developed fully. E.g. Henry speaks of what today we would call 'skeptical theism', the concept that God's omniscient grasp of goods so outstrips our own that what appears to us to be gratuitous (not having an ultimate redeeming value, or, alternatively, being an evil for which God has a morally sufficient reason for permitting) is not in fact gratuitous at all. The inductive inference from ' $x$ appears to be gratuitous' to ' $\mathrm{x}$ is in fact gratuitous' is one that Rowe thinks is a reasonable inference; Stephen Wykstra demurs-Wykstra's very important re- 
sponse to Rowe's article compares God's knowledge of possibly justificatory goods over evils to our own knowledge of such to that of a normally functioning, intelligent parent's knowledge compared to his one month old infant (Wykstra 1990). The literature on this inference is vast, but by 1983 was still, again, in its developmental stages. In the following decade, it would receive intense treatment. But overall here we should remember that Henry is giving us an overview of the material, and so we do not expect him to go into great detail on any one point. It is helpful to see that he is aware, though, of the various nuances of the topic, even if they are not greatly developed. And when the different emphases Henry chose to identify are developed within Henry's text, of course they are so unfolded in the context of the biblical theodicy-exactly what we had come to expect in Henry's magnum opus!

As a final criticism here, I would say the following. If one consults the textbook definitions of both compatibilism and incompatibilism, one will find that Henry's statements here (about human free will, cited just above) seem quite compatible with both camps. Thus, his statements underdetermine his exact vantage point regarding the freedom of the will. (Though it sure should be noted that the last sentence of the quoted paragraph, above, does sound like an admission of compatibilism, in agreement with John Feinberg's theodical position. However, Henry does not develop this substantially further.) Thus, I conclude that his treatment of the problem of evil could have been enhanced by taking up a definite position on the doctrine of the free action or free agency of (fallen) human beings, and working that through consistently and coherently in view of his other claims in GFA. On the other hand, it is a reality that some incompatibilists, e.g., will not be drawn to the account of freewill given by, say, a compatibilist, since they have no hope in reading such an account of finding something to strengthen or enlighten their own convictions about how to deal with the problem of evil given that account of free will. So, at least with respect to scoring high on the wideness of Henry's appeal, it may have been 'better' to do exactly what he did.

(2) Also, Henry does spend some amount of time sorting through the biblical hermeneutical issue of the meaning and proper interpretation of Isaiah 45:7, 'I form the light and create darkness, I bring prosperity and create disaster; I, the Lord, do all these things.' Obviously relevant to the problem of evil is what God's role is in natural disasters or any kind of 'disaster'. In short, his reply is to say that $\sin$ is one of one of the most disastrous of realities, but to attribute sin to God is entirely theologically a non-starter-it is unthinkable. Thus, Henry opts for the usual distinction between divine 'decree' and divine 'permission', opting for interpreting such passages as that 
in Isaiah as God's permission of disaster and natural disaster-not as the instigator proper of these events (Henry 1983: 301).

(3) We have yet to say much about Satan's rebellion against God, which according to Scripture brought evil into God's pristine creation for the first time. Henry's position here is unflashy and squarely biblical. There is a chief angel of light, originally made in goodness, yet turned to darkness by willing to rebel against God almighty. He was cast down, and looks now for souls that he can devour (1 Peter 5:8). He will never repent-Scripture holds out no hope for Satan to suddenly feel remorseful for his hatred of God or God's saints or the church, etc.- - and thus Satan will be consigned to everlasting darkness in the lake of fire.

\section{Conclusion: Henry's Synthesis of the Christian Revelation Response to Evil and Suffering}

In conclusion, Henry as a Christian theologian treats the problem of evil in fairly traditional ways. He doesn't stress philosophical, extra-biblical development of logical relationships, actual propositional presentations of the logical or evidential arguments from evil (e.g. as Epicurus, Hume, or William Rowe give us in their literature). He doesn't say there is a silver bullet answer to the problem; in fact, there are many different facets to the problem. But just as all the covenants are 'Yeah' and 'Amen' in Christ (2 Corinthians 1:20), so also the problems of evil seem to meet with a sufficient answer ultimately, in Henry's biblical theodicy, in God's purpose in Christ, and in Christ's suffering on our behalf. Even Satan's rebellion and his taunting God's saints as the 'accuser' of the brethren is met and trumped by the resurrection. 'Where, O death, is your victory? Where, O death, is your sting?' (1 Corinthians 15:55) There is a 'deeper magic' still that Satan doesn't understand-God's agape love through which he redeems souls made in God's very image who turn away from their rebellion and ultimate despair of departing from God's presence forever to embrace God's provision of forgiveness of sins and the restoration of the sullied divine image, divine adoption as God's sons and daughters, being put into union with Christ, etc. The terms good and evil are definable, receiving their sense and meaning based on God's character and nature and being in agreement with it (good) or in dire opposition to it (evil). The problem of evil and sin, death, and Satan always has an eschatological aspect to it: all creation groans and awaits renewal! And thus the theological virtue of hope enlivens as the Holy Spirit has been sent to remind us of the truths of the Gospel and fill us with a confident expectation of the all-perfect, omni-benevolent nature of the One who so loved us that he emptied himself, taking the form of a servant, to bear our sins in his body on the tree. By this act of grace, we may be set 
free from the law of sin and death and ultimately run free under the banner of faith, life, grace, and divine covenantal love.

Several critics of Henry have leveled the criticism that he is too beholden to the old, traditional critical-historical view of interpretation of Holy Writ. Kevin Vanhoozer praises Henry for being culturally sensitive, and alert to the fact that theology is cultural, and culture is theological. However, it's clear from other sections of Vanhoozer's book that Henry would fall into the camp Vanhoozer criticizes as 'the received view', which conceives of revelation as too propositional, among other things (Vanhoozer 2002: 134-139). Vanhoozer suggests an adaptation of John Searle's speech-act theory as a way to interpret what God actually does when God reveals himself in scripture, and to see the need for this neo-Searlean theory is to wade through and understand the alternative post-Kantian theories of hermeneutics, from Derrida to Rorty, Ricoeur and Marcuse. But ironically, the postmodern cannot deconstruct pain, suffering and death. The problem of evil itself is a reminder of these basic surd categories which themselves transcend one's interpretive grid for making sense of the universe-at least initially. There is a sense in which these phenomena are pre-critical (recalling that Kant's philosophy is called a 'critical' one, that is one that concludes that there are a priori structures of the human consciousness that actively interpret and change our perception of reality and ourselves) and are experienced precritically, in the sense that they are to some degree nonverbal and are preinterpretive. That is, one can be in the state of pain or suffering without that pain or suffering state being greatly enhanced or changed through interpretation because of one's worldview or ultimate commitments. Shortly after notices of Jacques Derrida's death went around, Greg Koukl sent out one of these notices, with the prefacing note, 'Derrida died: you can't deconstruct that' (personal correspondence). Whatever we make of the best way to conceive of God, revelation, and authority, we know that pain and suffering get through to all sentient creatures. Does an 18 th century Frenchman really feel the pain of a stubbed toe any differently from a 21 st century American? Praise God that God's love, also, registers: and God, in his awesome grace and mercy and power has made it clear to us, undeserving sinners, how we might come home and experience the ultimate defeat of evil, death and suffering, and enter into God's eternal and peaceable Kingdom.

\section{Afterword: A Personal Anecdote about Carl F. H. Henry (and me)}

I mentioned within the paper that I had the privilege of having Carl Henry for a Gospel of John course at Hillsdale College in 1985. In order to grasp the nature of the present anecdote, let me begin with this point. I grew up in Southwestern Michigan as a Catholic who always knew that God existed, 
and that we can pray to him and that he hears us and loves us. However, I was never taught the evangelical doctrine that Christ was 'delivered over to death for our sins' and raised again to life 'for our justification' (Romans 4:25). A friend invited me to a German Baptist Church (another parallel with Dr. Henry, as this was the church denomination under which he was first ordained and the one under which he received his ThD degree), and our pastor who had a ThD from Dallas Theological Seminary preached on Romans in the a.m. service, and Daniel in the p.m. service. Under those two great books, by the loving work of the Holy Spirit, I accepted Christ as my personal savior in November 1983.

But there were some incidents. One night months before that, when walking home from work on Saturday night at a restaurant. At a restaurant, I had stayed late to close down the salad bar and clean up. On this particular evening (like very few times-but definite, distinct times in my life) I felt a distinct need to go into this particular church on the way home. It's one of a handful of times that I felt physically drawn to a specific place. It was about $11 \mathrm{pm}$ at night, and the church was dark and closed up, and the parking lot perfectly empty. Yet, I went to the main door and-voilà! - the door was unlocked. Entering into the almost total darkness, I sat for a while in the sanctuary, and then made my way to the library. I took a book that night-a pretty inexpensive though hard back Bible-without thinking too much about the contradiction. In an interesting turn of events, by reading that book and following along with it during the preached word I heard several months later, I became a Christian during the Fall of my Senior year in High School. By graduation, my friends had given me a new leather-bound NIV Thompson Chain Reference Bible, and the older pilfered volume fell out of my focus, I confess.

I entered Hillsdale College in Hillsdale, Michigan, as a Freshman in Fall 1984. As I recall, in the Fall 1985 my roommate and suitemates were telling me that Carl Henry was teaching two classes as a visiting professor on campus at Hillsdale that Fall. I asked them, 'Who is Carl Henry?' They looked at me with some mixture of shock, horror and disbelief, 'You don't know who Carl Henry is?', they retorted. They proceeded to tell me that he was the founding editor of Christianity Today, that he practically single-handedly defined evangelicalism in the mid-20th century, and that he was the author of the recently published six volume God, Revelation, and Authority. They urged me to join the class on the Gospel of John that they were all taking that met on Monday evenings. So, I went. And it was a most delightful experienceeven if I didn't realize what a special occasion those classes were for such a young, inexperienced Christian student. It really was an excellent class, with a lot of rich insights to the Fourth Gospel (example: Henry stressed early on that to 'see' and understand the Gospel's unitative literary inten- 
tion and purpose, one needs to read the entire book all in one sitting. That is excellent advice). The first night witnessed Carl Henry giving his testimony. I do not remember all the details of his story, but according to a website, he was converted at the age of 20 years old by talking to a friend name Gene Bedford. ${ }^{1}$ I remember two important parts of the story, as Carl Henry told them. The first was that Henry said that he (too) had gone into a church at one point (!) and pilfered a Bible from the church (!), in a fashion uncannily similar to my story, with no particular intention to return the Bible shortly thereafter. (Yes, we had both done the same thing.) When Henry told this part of the story, my roommate and suitemates were elbowing me in disbelief, saying, 'You've got to tell him! You've got to tell him!' At the first break, I approached Henry and told him of my experience-and of the similar book-acquiring practice in our narratives-not knowing exactly what he would respond. He suddenly looked at me very seriously and asked, 'Do you still have that Bible?' 'Yes', I told him. 'Then you must return it.' 'Yes, sir, I will', I responded to him. During the next time at home, I dutifully took the pilfered book and went to the church and met with the pastor and told him my story. Thankfully, he thought it was all quite hilarious, and invited me to keep the Bible. The rest of the story, I suppose, is that my father, many years later, became in semi-retirement the church janitor at the same church (though I had never told him this story). Imagine my amusement when my dad, who knows I love books, during the annual church rummage sale the first year or so he was serving there, saved back a fairly sizeable box of books for me, which included about 5-6 of that exact same type of Bible that I had acquired so many years earlier. God is merciful, and God has a particular lively sense of providential humor, it has always struck me, since having these experiences. But I know this much: It was a great privilege to get to study that semester under Carl Henry, and I will forever be in his debt. Thank you, Lord, and thank you for your faithful servant, Carl Henry.

\section{Bibliography}

Feinberg JS (2004) The Many Faces of Evil. Revised and expanded edition. Wheaton, IL: Crossway Books.

Feinberg JS (1979) Theologies and Evil. Washington, DC: University Press of America.

1 Some very helpful information about Carl Henry's life can be found in some of the Wheaton College archives. See http://www2.wheaton.edu/bgc/archives/GUIDES/-628.htm. 
Henry CFH (1983) God, Revelation, and Authority. Volume 6. Waco, TX: Word.

Henry CFH (1957) Personal Christian Ethics. Grand Rapids: William B. Eerdmans Publishing Co.

Henry CFH (1948) Remaking the Modern Mind. Grand Rapids, MI: William B. Eerdmans Publishing Co.

Hick J (1977) Evil and the God of Love. Revised edition. New York, NY: HarperCollins.

Kant I (1981) Grounding for the Metaphysics of Morals. Edited and translated by James W. Ellington. Indianapolis: Hackett Publishing Co.

Kant I (1965) The Critique of Pure Reason. Edited and translated by Norman Kemp Smith. New York, NY: St. Martin's Press.

Lewis CS (1960) Mere Christianity. New York, NY: Macmillan.

Linville MD (1990) On Goodness: Human and Divine. American Philosophical Quarterly 27(2): 143-152.

Madden EH and Hare PH (1968) Evil and the Concept of God. Springfield, IL: Charles C. Thomas Publisher.

Moore GE (1903) Principia Ethica. Cambridge: Cambridge University Press.

Patterson BE (1983) Carl F. H. Henry. Waco, TX: Word Books.

Plantinga A (1974) God, Freedom and Evil. Grand Rapids, MI: Eerdmans Publishing Co.

Rowe WL (1978) Philosophy of Religion: An Introduction. Belmont, CA: Wadsworth Publishing Co.

Rowe WL (1979) The Problem of Evil and Some Varieties of Atheism. American Philosophical Quarterly 16(*): 335-341.

Vanhoozer KJ (2002) First Theology. Downers Grove, IL: InterVarsity Press.

Wykstra SJ (1990) The Humean Obstacle to Evidential Arguments from Evil: On Avoiding the Evils of 'Appearance'. In Adams RW and Adams MM (eds) The Problem of Evil. New York, NY: Oxford University Press, pp. 138-160. 